\title{
Factors affecting the capture of dietary nitrogen by micro-organisms in the forestomachs of the young steer. Experiments with $\left[{ }^{15} \mathrm{~N}\right]$ urea
}

\author{
BY D. N. SALTER, R. H. SMITH AND D. HEWITT \\ National Institute for Research in Dairying, Shinfield, Reading RG2 9AT
}

(Received 12 January 1983-Accepted 19 April 1983)

\begin{abstract}
1. For a period of at least 2 weeks before an experimental collection each of four young steers received total daily intakes consisting of approximately $(\mathrm{g} / \mathrm{kg}) 600$ straw and 400 concentrates with the nitrogen provided mainly as urea and in which the main energy source was starch (tapioca) for diet 1 and glucose for diet 2 . Concentrates were given twice daily at about 09.00 and 17.00 hours, straw at 17.00 hours only. The value for the ratio, rumen-degradable $\mathrm{N}$ : metabolisable energy $(\mathrm{g} / \mathrm{MJ})$ in the daily intake was estimated to be approximately $1 \cdot 2$.

2. On the day that an experimental collection was to be made the urea normally given in the feed at 09.00 hours was labelled with ${ }^{15} \mathrm{~N}$. This urea and sometimes the appropriate energy source were added either as a single dose (SD) at 09.00 hours or in three equally-divided doses (DD) at $09.00,11.00$ and 13.00 hours. Treatments, given in a Latin-square design, were: (A), starch (SD) + urea (SD); (B), starch (SD) + urea (DD); (C), glucose (SD) + urea (DD); (D), glucose (DD) + urea (DD). Doses of polyethylene glycol (PEG) and ${ }^{144} \mathrm{Ce}$ (as cerous chloride) were given as markers with the urea.

3. After these doses were given, samples of abomasal and duodenal digesta were taken periodically for $72 \mathrm{~h}$. It appeared that virtually all the PEG had left the rumen by this time and mean recovery of ${ }^{144} \mathrm{Ce}$ relative to PEG was approximately $90 \%$. From recoveries of non-ammonia- ${ }^{15} \mathrm{~N}$ (microbial ${ }^{15} \mathrm{~N}$ ) at the abomasum, estimated relative to $P E G$, values for mean fractional efficiencies of conversion of urea- $N$ to microbial- $N$ were calculated to be $0.59,0.59,0.40$ and 0.41 for treatments $\mathrm{A}, \mathrm{B}, \mathrm{C}$ and $\mathrm{D}$ respectively. Values for treatments $\mathrm{A}$ and $\mathrm{B}$ were significantly greater than those for treatments $C$ and $D$ but no other differences were significant. Examination of duodenal samples led to similar conclusions.

4. It was concluded that starch was a more suitable energy source than glucose for maximal capture of ammonia- $N$ for microbial synthesis but that spreading the urea and glucose doses in an attempt to match energy and ammonia release rates had no significant effect on capture efficiency.
\end{abstract}

Nitrogen incorporated into rumen bacteria may come from the diet or it may be of endogenous origin. The latter may come from various sources: urea in saliva, urea passing from blood to rumen across the rumen wall, or cells sloughed from the rumen wall (MacRae et al. 1979). Amounts of endogenous material and particularly of urea crossing the rumen wall may vary widely (Kennedy \& Milligan, 1981) so that interpretation of simple balance measurements of $\mathbf{N}$ consumed in relation to duodenal $\mathbf{N}$ flow is difficult.

As a general rule, if dietary $\mathrm{N}$ intake is high there is a net loss of $\mathrm{N}$ between mouth and duodenum, whilst if it is low there is a net gain (Agricultural Research Council, 1980). However, results may vary very much with conditions and, in particular, if urea forms a substantial proportion of the dietary $\mathbf{N}$ major differences in the apparent efficiency of $\mathbf{N}$ capture with continuous rather than intermittent feeding may occur (Meggison et al. 1979). To clarify this issue it would clearly be desirable to measure directly in vivo how effectively a particular dietary $\mathbf{N}$ source is utilized by the rumen microbial population for protein synthesis.

Earlier studies have made use of an ${ }^{15} \mathrm{~N}$ label for this purpose (Nolan \& MacRae, 1976; Salter \& Smith, 1977a, 1979). Salter \& Smith (1979), for example, carried out in vivo studies with steers which were given single test feeds of isonitrogenous, isoenergetic diets containing urea or decorticated groundnut meal protein as the main $\mathrm{N}$ source. It was found that when urea was the only $\mathrm{N}$ source, ${ }^{15} \mathrm{~N}$ was much less well utilized than when urea comprised only $15 \%$ of the N.

Possible reasons for the relative inefficiency of utilization of urea-N under these conditions may have been that rates of release of ammonia and energy from urea and 
Table 1. Composition of experimental feeds during the experiments

\begin{tabular}{|c|c|c|c|c|c|c|c|}
\hline \multirow{2}{*}{$\begin{array}{r}\text { Treatment } \quad \ldots \\
\text { Time of feeding (hours) }\end{array}$} & \multirow{2}{*}{$\frac{A}{09.00}$} & \multicolumn{2}{|c|}{ B } & \multicolumn{2}{|c|}{ C } & \multicolumn{2}{|c|}{ D } \\
\hline & & 09.00 & $\begin{array}{l}11.00 \\
13.00\end{array}$ & 09.00 & $\begin{array}{l}11.00 \\
13.00\end{array}$ & 09.00 & $\begin{array}{l}11.00 \\
13.00\end{array}$ \\
\hline Tapioca (kg) & 0.375 & 0.375 & - & - & - & - & - \\
\hline Glucose $(\mathrm{kg})$ & - & - & - & 0.325 & - & $0 \cdot 108$ & $0 \cdot 108$ \\
\hline Urea $(g)$ & $12 \cdot 6$ & $4 \cdot 17$ & $4 \cdot 17$ & $4 \cdot 17$ & $4 \cdot 17$ & $4 \cdot 17$ & $4 \cdot 17$ \\
\hline${ }^{15} \mathrm{~N}$-urea $(\mathrm{g})^{*} \ddagger$ & 5.0 & 1.67 & 1.67 & $1 \cdot 67$ & 1.67 & $1 \cdot 67$ & 1.67 \\
\hline PEG $(\mathrm{g}) \ddagger$ & 100 & $33 \cdot 3$ & $33 \cdot 3$ & $33 \cdot 3$ & $33 \cdot 3$ & $33 \cdot 3$ & $33 \cdot 3$ \\
\hline${ }^{144} \mathrm{CeCl}_{3}(\mu \mathrm{Ci}) \dagger$ & 50 & $16 \cdot 7$ & $16 \cdot 7$ & $16 \cdot 7$ & $16 \cdot 7$ & $16 \cdot 7$ & $16 \cdot 7$ \\
\hline
\end{tabular}

PEG, polyethylene glycol (molecular weight 4000).

* 30.5 atoms $\%$ excess ${ }^{15} \mathrm{~N}$.

$\dagger$ Nominal dose.

$\ddagger$ Made up to $500 \mathrm{ml}$ in dilute saline $(9 \mathrm{~g}$ sodium chloride $/ 1$ ).

carbohydrate were not matched or occurred too rapidly resulting in excessively-high rumen ammonia concentrations and losses of ammonia by absorption through the rumen wall. This explanation was put forward by Meggison et al. (1979) to explain a much better apparent capture of urea- $\mathrm{N}$ when urea was given continuously rather than in two meals each day. The experiments reported here were carried out to study the effects in four young steers of varying the relative rates of supply of $\mathrm{N}$ and energy, and of the form of carbohydrate, on the incorporation of urea- $\mathrm{N}$ labelled with ${ }^{15} \mathrm{~N}$ into rumen bacteria. Estimates were based on relative recoveries of the non-absorbed marker polyethylene glycol (molecular weight 4000 ; PEG) and non-ammonia- ${ }^{15} \mathrm{~N}\left(\mathrm{NA}-{ }^{15} \mathrm{~N}\right.$ ). To check that this technique was satisfactory even though PEG and ${ }^{15} \mathrm{~N}$ moved at different rates the relative recoveries of PEG and the slowly-moving particulate marker ${ }^{144} \mathrm{Ce}$ (Huston \& Ellis, 1968) were also examined.

\section{EXPERIMENTAL}

\section{Animals and feeding}

For a period of at least 2 weeks before an experimental collection was made, four Friesian steers aged 24-31 weeks, weighing 100-120 kg and fitted with rumen, abomasal and simple duodenal cannulas, received either diet 1 ( $1 \mathrm{~kg}$ straw (given at the evening feed only), $375 \mathrm{~g}$ tapioca and $17.5 \mathrm{~g}$ urea (given twice daily, morning and evening)), or diet 2 (1 kg straw (given in the evening), $325 \mathrm{~g}$ glucose and $17.5 \mathrm{~g}$ urea twice daily). On the morning of an experiment appropriate experimental feeds (treatments A-D; Table 1) were given by direct addition to the rumen. Steers that had received diet 1 were given tapioca (coarsely ground to approximately $1-2 \mathrm{~mm}$ particle size), urea, ${ }^{15} \mathrm{~N}$-labelled urea and PEG. Steers that had received diet 2 were given glucose and urea together with amounts of ${ }^{15} \mathrm{~N}$-labelled urea and PEG. These components and ${ }^{144} \mathrm{Ce}$ (as cerous chloride) were given either as single doses (SD) at 09.00 hours or subdivided into three doses (DD) given at $09.00,11.00$ and 13.00 hours as shown in Table 1. After the components of the test feed, no further feeds were given for $24 \mathrm{~h}$ and water was withheld for a period of $7 \mathrm{~h}$ after the first test solution was administered. The pre-experimental feeding pattern was resumed after $24 \mathrm{~h}$. The main characteristics of the four treatments were: (A), starch (SD) + urea (SD); (B), starch (SD) + urea (DD); (C), glucose (SD) + urea (DD); (D), glucose (DD) + urea (DD). Each of the four steers received the four treatments in four periods according to a $4 \times 4$ Latin-square design, with the restriction that each steer had only one change of diet. Thus each steer was given the same diets in periods 2 and 4 that it had received in periods 1 and 3 respectively. 


\section{Collection of contents of rumen, abomasum and duodenum}

Samples of the contents of the abomasum $(200 \mathrm{~g})$ and duodenum $(200 \mathrm{~g})$ were collected immediately before first administering the $\left[{ }^{15} \mathrm{~N}\right]$ urea and at $1,3,5,7,10,15,24,32,48,56$ and $72 \mathrm{~h}$ afterwards. Collections were made simply by removing the caps of the cannulas and allowing the contents to flow out. Samples of rumen contents (approximately $350 \mathrm{~g}$ ) were collected before administering the $\left[{ }^{15} \mathrm{~N}\right]$ urea and at $1,3,5,7$ and $24 \mathrm{~h}$ afterwards by means of a pump. To ensure that each sample contained material reasonably representative of the total rumen fluid, the pump inlet tube was moved to different positions in the rumen during collection.

\section{Isotopes}

$\left[{ }^{15} \mathrm{~N}\right]$ urea (30.5 atoms \%), double N-labelled, was obtained from British Oxygen Co. Ltd, London. ${ }^{144} \mathrm{Ce}(10 \mathrm{mCi})$ was obtained as cerous chloride in $1 \mathrm{M}$-hydrochloric acid from Amersham International, Amersham, Bucks.

\section{Analytical methods}

Processing and analysis of digesta samples. Samples of rumen contents were first strained through several layers of muslin to remove coarse particulate material. $\mathrm{HCl}(2 \mathrm{M})$ was added at the rate of $200 \mathrm{ml} / 1$ fluid to prevent loss of ammonia. The samples were centrifuged and the supernatant fractions analysed for total ammonia and ammonia- ${ }^{15} \mathrm{~N}$. Whole abomasal and duodenal samples were homogenized and analysed for ${ }^{144} \mathrm{Ce}$, total $\mathrm{N}$, dry matter and total ${ }^{15} \mathrm{~N}$. Subsamples were centrifuged at $12000 \mathrm{~g}$ for $20 \mathrm{~min}$ at $1^{\circ}$ (MSE High Speed 18 centrifuge) and the clear supernatant fractions and sediments separated. PEG, dry matter, ammonia- $\mathrm{N}$ and ammonia- ${ }^{-15} \mathrm{~N}$ were determined in the supernatant fractions.

Total N, ammonia-N, PEG and dry matter were measured as previously described (Salter \& Smith, $1977 b$; Salter et al. 1979). Total- and ammonia- ${ }^{15} \mathrm{~N}$ were measured in ammonium chloride prepared, respectively, by a Kjeldahl digestion and distillation method or by a microdiffusion method (Conway, 1957) from samples of digesta (or fractions prepared from them) by means of the NIRD automatic ${ }^{15} \mathrm{~N}$ analyser (Goulden \& Salter, 1979).

Measurement of ${ }^{144} \mathrm{Ce}$. Samples $(1 \mathrm{~g})$ of whole homogenized abomasal or duodenal digesta were weighed into disposable plastic scintillation tubes inserted into glass scintillation vials and the radioactivity measured by solid scintillation counting using a Panax 160 automatic gamma counter.

Calculation of efficiency of ${ }^{15} \mathrm{~N}$ incorporation in rumen bacteria. The amount of $\mathrm{NA}-{ }^{15} \mathrm{~N}$ recovered in abomasal and duodenal samples was calculated from the measured weight excess of ${ }^{15} \mathrm{~N}$ and expressed as a proportion of the given ${ }^{15} \mathrm{~N}$ dose per $\mathrm{kg}$ digesta collected, for each of the time-points up to $72 \mathrm{~h}$. Similarly the proportions of the PEG and ${ }^{144} \mathrm{Ce}$ doses recovered per $\mathrm{kg}$ digesta were calculated and the results plotted $v$. time. Since all the NA- ${ }^{15} \mathrm{~N}$ reaching the abomasum and duodenum may be assumed to have been incorporated into bacteria, the proportion of the ${ }^{15} \mathrm{~N}$ incorporated may, making certain assumptions (see p. 431) be estimated from the area under the ${ }^{15} \mathrm{~N}$ curve relative to that under the curves of either of the non-absorbed markers PEG or ${ }^{144} \mathrm{Ce}$.

Statistical treatment of results. Standard analysis of variance for a Latin-square design was applied to the results and mean values with their standard errors of differences with $6 \mathrm{df}$ are given in Tables 2 and 3.

\section{RESULTS}

\section{Rumen ammonia concentrations}

Results are summarized in Fig. 1 and show that administration of the urea in three equal portions over a period of $4 \mathrm{~h}$ (treatments B, C, D, Table 1) resulted in a reduction in the maximum concentration of ammonia compared with that reached when urea was given as 


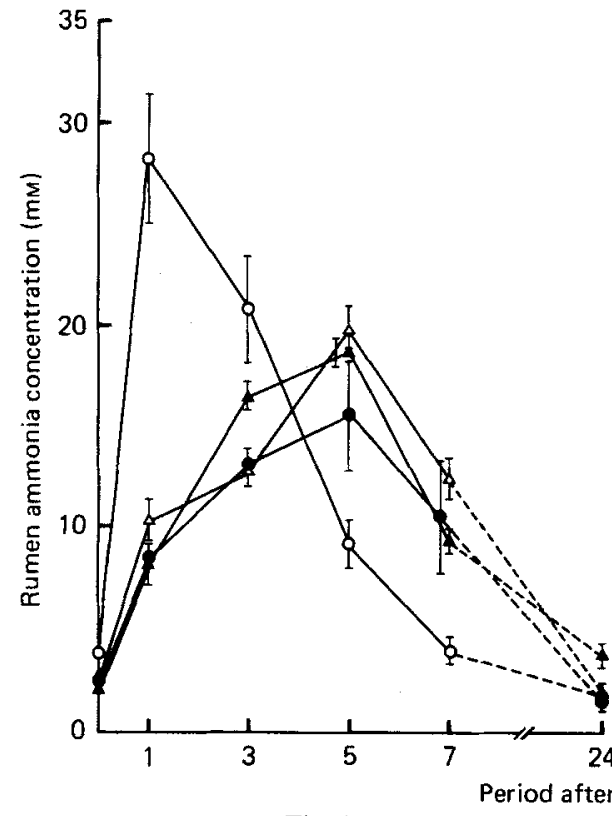

Fig. 1.

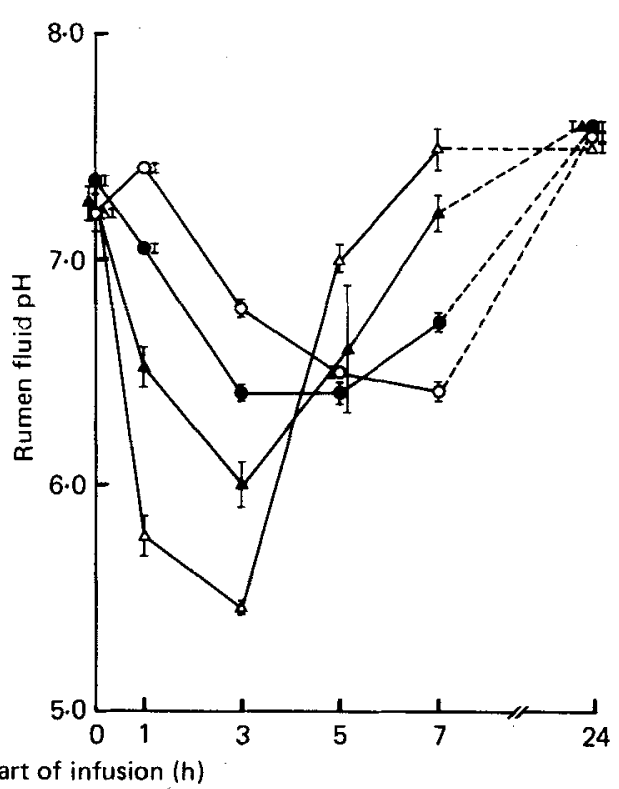

Fig. 2.

Fig. 1. Rumen ammonia concentrations in steers given diet treatments with single (SD) or divided (DD) doses: (O), A, starch (SD) + urea (SD); (O), B, starch (SD) + urea (DD); $\triangle$ ), C, glucose (SD) + urea (DD); (A), D, glucose (DD) + urea (DD). For details of treatments A, B, C, D, see p. 428. Points are mean values with their standard errors represented by vertical bars for four steers.

Fig. 2. $\mathrm{pH}$ values for rumen fluid in steers given diet treatments with single (SD) or divided (DD) doses: (O), A, starch (SD) + urea (SD); (O), B, starch (SD) + urea (DD); $(\Delta)$, C, glucose (SD) + urea (DD); (A), D, glucose (DD) + urea (DD). For details of treatments A, B, C, D, see p. 428 . Points are mean values with their standard errors represented by vertical bars for four steers.

a single dose (treatment A). The peak concentration was delayed from approximately $1 \mathrm{~h}$ after the first feed with treatment A to approximately $5 \mathrm{~h}$ with treatments $\mathrm{B}, \mathrm{C}$ and $\mathrm{D}$.

\section{Rumen $p H$}

The results are summarized in Fig. 2 and show that mean rumen $\mathrm{pH}$ values in the pre-feeding state were always similar at approximately $7 \cdot 2-7 \cdot 4$. Minimum mean values of $6 \cdot 4-6 \cdot 5$ were observed after giving the starch diets (after 3-5 and 5-7 h respectively for treatments $\mathrm{A}$ and B) and the $\mathrm{pH}$ returned to near the pre-feeding level after $24 \mathrm{~h}$. With treatments $\mathrm{C}$ and $\mathrm{D}$, lower minimum $\mathrm{pH}$ values of 5.5 and 6.1 respectively were reached more rapidly (after $3 \mathrm{~h}$ ) and the $\mathrm{pH}$ returned to the pre-feeding value after $7 \mathrm{~h}$.

\section{Relative recoveries of ${ }^{15} \mathrm{~N}, \mathrm{PEG}$ and ${ }^{144} \mathrm{Ce}$ at the abomasum and duodenum}

Typical examples of the patterns of flow of ${ }^{15} \mathrm{~N}, \mathrm{PEG}$ and ${ }^{144} \mathrm{Ce}$ in the abomasal contents of a steer on treatment A are shown in Fig. 3. Duodenal flow patterns were closely similar to those shown for abomasal contents. Similar patterns were seen for the other diets and steers although, particularly between steers, there were differences in the times of peak concentrations; for example, peak PEG concentrations generally occurred between 3 and $5 \mathrm{~h}$ after infusion. However, relations between patterns for the different components remained approximately the same and peak concentrations of ${ }^{144} \mathrm{Ce}$ in both abomasal and 


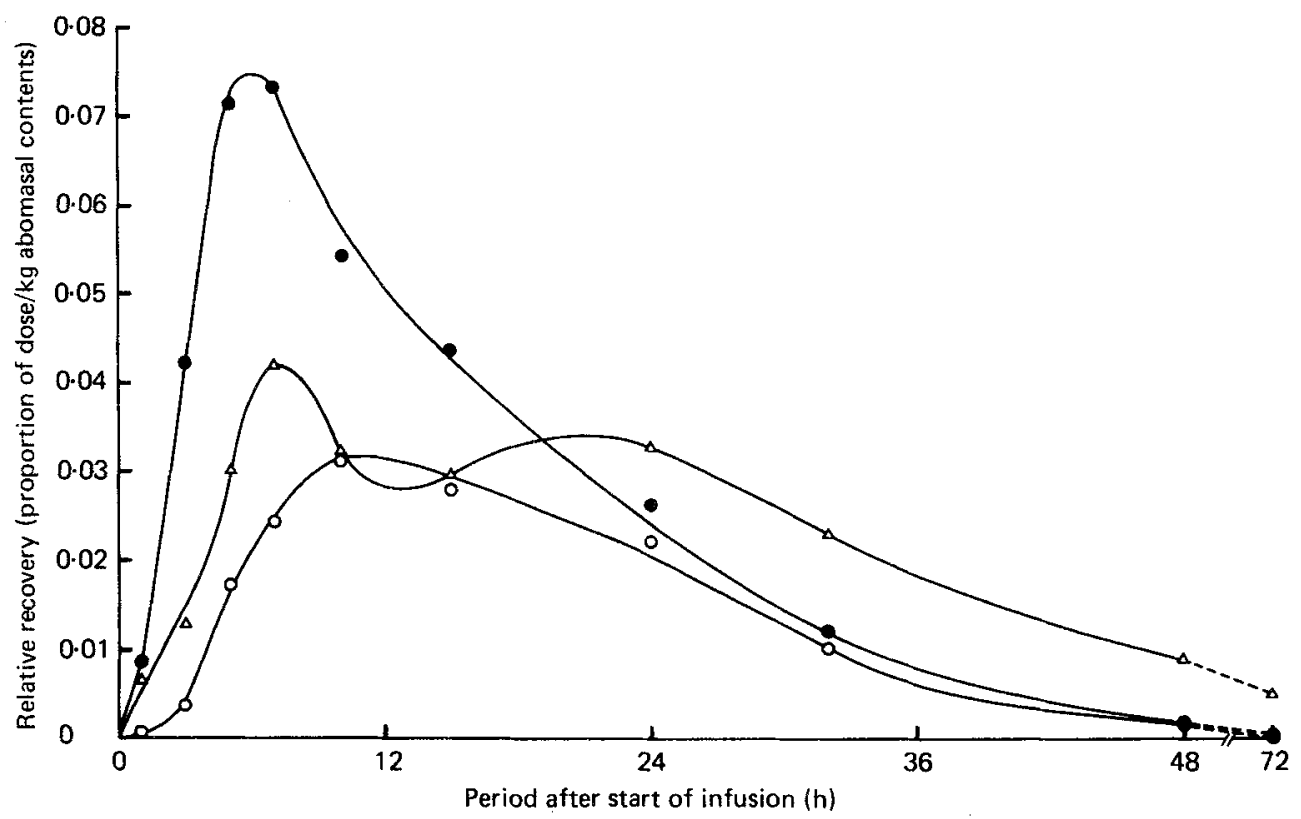

Fig. 3. Relative recoveries of infused doses of $(O),{ }^{15} \mathrm{~N} ;(O)$, polyethylene glycol (molecular weight 4000); $(\triangle),{ }^{144} \mathrm{Ce}$ in the abomasal contents of a steer given treatment $\mathrm{A}$ (starch and urea given in single doses).

Values are expressed as proportions of the given dose per $\mathrm{kg}$ abomasal contents collected.

duodenal contents were reached approximately $1 \mathrm{~h}$ later than those of PEG. The maximum concentrations of NA- ${ }^{-15} \mathrm{~N}$ generally occurred 3-5 h after the PEG peak.

Table 2 shows the relative estimated flows in arbitrary units of ${ }^{15} \mathrm{~N}, \mathrm{PEG}$ and ${ }^{144} \mathrm{Ce}$ in duodenal and abomasal samples up to 24,48 or $72 \mathrm{~h}$ after the first infusion. Assuming that the only way that PEG left the rumen was with the digesta flow, its recovery appeared to be complete in $72 \mathrm{~h}$ (i.e. it was no longer detectable in samples) and nearly complete in $48 \mathrm{~h}$, as there was an increase in recovery of only $2-7 \%$ between 48 and $72 \mathrm{~h}$. In contrast to this, appreciable concentrations of ${ }^{144} \mathrm{Ce}$ were detected in abomasal and duodenal digesta up to $72 \mathrm{~h}$ and the increase in ${ }^{144} \mathrm{Ce}$ recovery between 48 and $72 \mathrm{~h}$ ranged from 17 to $37 \%$.

After $24 \mathrm{~h}$ less than half as much ${ }^{144} \mathrm{Ce}$ as PEG was recovered but by $72 \mathrm{~h}$ relative ${ }^{144} \mathrm{Ce}$ recoveries closely approached those of PEG (Table 2) and it appeared that for this period estimates of ${ }^{15} \mathrm{~N}$ recovery could reasonably be based on either marker. Such estimates based on PEG in Table 3 appear therefore to be valid. For shorter collection periods recoveries of NA-15 N relative to PEG were smaller undoubtedly due, in part, to a more rapid flow of PEG than of ${ }^{15} \mathrm{~N}$ from the rumen, although it is probable that part of the difference was due to the inclusion of small amounts of recycled ${ }^{15} \mathrm{~N}$ in the longer sampling periods.

Although mean estimates of ${ }^{15} \mathrm{~N}$ incorporated into rumen microbes at the duodenum based on $72 \mathrm{~h}$ collections (Table 3) were greater for treatment $B$ than for treatment $\mathrm{A}$, the difference was not significant and was not supported by observations made at the abomasum. Results for abomasal sampling in fact showed a lower coefficient of variation $(18 \%)$ than for duodenal sampling $(23 \%)$. Thus it appeared that spreading the urea dose had little effect on ${ }^{15} \mathrm{~N}$ capture efficiency. There were no significant differences between results for treatments $C$ and $D$ so that spreading the glucose dose was equally without effect. However, taken together the starch-containing diets (treatments A and B) gave significantly 
Table 3. Recovery of non-ammonia- ${ }^{15} \mathrm{~N}$ (microbial ${ }^{15} \mathrm{~N}$ ) relative to $P E G$ (non-ammonia ${ }^{15} \mathrm{~N}: \mathrm{PEG}$ ) at different times after dosing

(Mean values with their standard errors of differences (SED))

\begin{tabular}{|c|c|c|c|c|c|c|c|}
\hline \multirow{2}{*}{$\begin{array}{l}\text { Sampling } \\
\text { site }\end{array}$} & \multirow{2}{*}{$\begin{array}{l}\text { Duration of } \\
\text { sampling } \\
\text { (h) }\end{array}$} & \multicolumn{4}{|c|}{ Treatment } & \multirow[b]{2}{*}{ SED } & \multirow{2}{*}{$\begin{array}{c}\text { Statistical } \\
\text { significance of } \\
\text { treatment effect }\end{array}$} \\
\hline & & $\mathbf{A}$ & B & C & D & & \\
\hline Abomasum & $\begin{array}{l}1-24 \\
1-48 \\
1-72\end{array}$ & $\begin{array}{l}0.387 \\
0.524 \\
0.593\end{array}$ & $\begin{array}{l}0.440 \\
0.525 \\
0.591\end{array}$ & $\begin{array}{l}0 \cdot 244 \\
0 \cdot 336 \\
0.399\end{array}$ & $\begin{array}{l}0.191 \\
0.318 \\
0.407\end{array}$ & $\begin{array}{l}0.0524 \\
0.0523 \\
0.0636\end{array}$ & ** \\
\hline Duodenum & $\begin{array}{l}1-24 \\
1-48 \\
1-72\end{array}$ & $\begin{array}{l}0.389 \\
0.492 \\
0.538\end{array}$ & $\begin{array}{l}0.473 \\
0.557 \\
0.643\end{array}$ & $\begin{array}{l}0.257 \\
0.331 \\
0.399\end{array}$ & $\begin{array}{l}0.229 \\
0.340 \\
0.433\end{array}$ & $\begin{array}{l}0.0640 \\
0.0654 \\
0.0806\end{array}$ & * \\
\hline
\end{tabular}

PEG, polyethylene glycol (molecular weight 4000).

$\dagger P \leqslant 0.10, * P \leqslant 0.05, * * P \leqslant 0.01$.

better ${ }^{15} \mathrm{~N}$ utilization than the glucose diets (treatments $\mathrm{C}$ and D) (abomasum $P<0.05$, duodenum $P<0 \cdot 10$ ).

\section{DISCUSSION}

The heterogeneous nature of ruminant digesta means that different components leave the rumen at different rates. This was shown in the present experiments by the different recovery patterns of single doses of the water-soluble marker (PEG) and the particulate marker ${ }^{144} \mathrm{Ce}$ respectively at the abomasum and duodenum. The unusual pattern of ${ }^{144} \mathrm{Ce}$ flow with peak concentrations at approximately 7 and $24 \mathrm{~h}$ after infusion as shown in Fig. 3 was found consistently both in abomasal and duodenal samples and was probably not, therefore, due to sampling error. It presumably indicated retention of ${ }^{144} \mathrm{Ce}$ on particles of different size in the rumen. It may, nevertheless, be expected that as long as collection is made for a sufficient period total recovery can be achieved for both markers. In the present study $72 \mathrm{~h}$ appeared to be long enough for nearly complete recovery of ${ }^{144} \mathrm{Ce}$ and presumably, therefore, also of ${ }^{15} \mathrm{~N}$ incorporated into microbial matter. The assessment of relative flows of different digesta components on an arbitrary scale by integrating their concentrations in duodenal or abomasal digesta in terms of the dose added, is valid as long as the total digesta flow-rate at these sites remains reasonably constant. This has been shown to be true in other experiments with calves given similar diets once or twice a day (J. L. Black, I. J. F. Stobo, J. H. B. Roy, P. Ganderton and E. F. Smith, unpublished results). If it were so during the present collection period and it were to be assumed that ${ }^{15} \mathrm{~N}$ once absorbed did not return to the rumen in appreciable amounts, it would be reasonable to suppose that relative recovery of NA-15 N to PEG at the abomasum or duodenum over $72 \mathrm{~h}$ would represent the true efficiency of capture of the urea- $\mathrm{N}$ added to the rumen (as a single dose or divided doses) at the start of an experimental period. In fact some recycling must have occurred (Kennedy \& Milligan, 1981). It is not possible to estimate the extent of this accurately but under the conditions of this experiment approximately $70 \%$ of the ${ }^{15} \mathrm{~N}$ dose would be absorbed of which approximately $75 \%$ would be deposited in tissue (Agricultural Research Council, 1980; D. N. Salter and R. H. Smith, unpublished results). Of the remainder, some would be excreted in urine and into the large gut so it is reasonable to suppose that no more than $15 \%$ of the ${ }^{15} \mathrm{~N}$ dose would re-enter the rumen in the $72 \mathrm{~h}$ period. It appears likely that, whereas the ${ }^{144} \mathrm{Ce}$ entering the abomasum in the $48-72 \mathrm{~h}$ recovery period must represent the final emergence of the last amounts retained in the rumen, much of the small amount of ${ }^{15} \mathrm{~N}$ appearing in that time would have been absorbed and recycled. It must be concluded 
therefore that the calculated values for direct incorporation of urea- $\mathrm{N}$ into microbial $\mathrm{N}$ shown in Table 3 are slight over-estimates.

Nevertheless, the results support earlier findings (Mathison \& Milligan, 1971; Nolan \& MacRae, 1976; Salter \& Smith, 1977a) in indicating that even under conditions favourable to efficient use of rumen-degradable $\mathrm{N}$ (RDN) for microbial synthesis, the capture of ammonia- $\mathrm{N}$ is far from complete.

There is no reason to suppose that the extent of recycling and, therefore, of possible over-estimation would have been appreciably different for the different treatments used. Total RDN intakes were similar for all treatments as were the total amounts of readilyavailable energy provided. No rumen $\mathrm{pH}$ values were sufficiently high to suggest the possibility of massive ammonia absorption through the rumen wall (Chalmers et al. 1971) and, indeed, the diets leading to the most efficient utilization gave the highest rumen $\mathrm{pH}$ values. Average rumen ammonia concentrations over the first $7 \mathrm{~h}$ after starting the experimental treatments were closely similar at approximately $10-13 \mathrm{~mm}$ with the only clear difference being a higher initial and lower final concentration for treatment A. It seems, therefore, that observed differences between the treatments (Table 3) reflected, in the main, differences in true capture efficiencies of urea-N.

The finding that spreading the urea dose, when starch formed the energy source, had no effect on capture efficiency did not support the idea that matching the release of ammonia- $\mathrm{N}$ to the release of usable energy necessarily improves $\mathbf{N}$ utilization. In fact it appeared that although ammonia concentration was relatively high soon after the urea was given in a single dose (treatment A), enough of this ammonia remained available in the rumen subsequently to provide an adequate $\mathrm{N}$ supply for the microbial population. In this respect the results were in agreement with earlier findings in lambs that giving urea continuously or in frequent small doses rather than twice daily did not improve $\mathrm{N}$ utilization (Knight \& Owens, 1973; Streeter et al. 1973). The results are, however, contrary to those of Meggison et al. (1979) who found a dramatic improvement in apparent capture efficiency of urea-N when urea was given continuously rather than intermittently to adult cattle. It is not clear what experimental differences may have been responsible for the apparent discrepancy but it is likely that responses would be influenced by factors affecting ammonia absorption from the rumen, in particular rumen $\mathrm{pH}$ (Smith, 1975). In the present experiments rumen $\mathrm{pH}$ was sufficiently low during the time of likely maximal microbial activity to minimize loss of ammonia by absorption across the rumen wall.

The reason why replacing starch by glucose as the main energy source led to a marked depression in the proportion of dietary urea- $\mathrm{N}$ captured for microbial growth is not clear. The possibility that a very rapid fermentation of energy may in itself have led to an inefficient use of ATP was not supported by the finding that spreading the glucose dose had no effect on capture efficiency. It is known, however, that diets based on very soluble carbohydrates such as molasses or sugar cane lead to a different microbial population to that resulting when a starch diet is given (Demeyer, 1981) and to different end-products of fermentation (Marty \& Preston, 1970). Although no direct measurements of microbial synthetic efficiency in terms of energy fermented were made in the present studies, the results indicated a reduction in net microbial protein synthesis when glucose rather than starch was given.

The present results support earlier findings (Salter \& Smith, 1977a) in showing rather poor utilization of urea- $\mathbf{N}$ for microbial synthesis when urea is the main $\mathbf{N}$ source. It seems unlikely for animals of the kind used in the present study and given starch-based diets with little true protein that any form of non-protein- $\mathrm{N}$ manipulation would improve proportional efficiency above about 0.6 .

The present and earlier findings show some of the factors likely to influence the capture of RDN for synthesis of microbial N compounds. Such information is needed if scientifically- 
based schemes of economic $\mathrm{N}$ rationing such as that proposed by the Agricultural Research Council (1980) are to be developed for practical use. It is, however, important that further information on absolute $\mathrm{N}$ capture efficiencies is obtained.

The authors would like to thank Mrs K. Smith and Mrs A. Hudson for excellent technical assistance.

\section{REFERENCES}

Agricultural Research Council (1980). The Nutrient Requirements of Ruminant Livestock. Slough: Commonwealth Agricultural Bureaux.

Blake, J. S. (1981). Studies with ${ }^{15} \mathrm{~N}$ on amino acid metabolism in rumen bacteria. PhD Thesis, University of Reading.

Chalmers, M. I., Jaffray, A. E. \& White, F. (1971). Proceedings of the Nutrition Society 30, 7-17.

Conway, E. J. (1957). Microdiffusion Analysis and Volumetric Error, p. 98. London: Crosby and Lockwood.

Demeyer, D. I. (1981). Agriculture and Environment 6, 295-337.

Goulden, I. D. S. \& Salter, D. N. (1979). Analyst 104, 756-765.

Huston, J. E. \& Ellis, W. C. (1968). Journal of Agricultural and Food Chemistry 16, 225-230.

Kennedy, P. M. \& Milligan, L. P. (1981). Canadian Journal of Animal Science 60, 205-221.

Knight, W. M. \& Owens, F. N. (1973). Journal of Animal Science 36, 145-149.

MacRae, J. B., Milne, J. A., Wilson, S. \& Spence, A. M. (1979). British Journal of Nutrition 40, $525-534$.

Marty, R. J. \& Preston, F. R. (1970). Revista Cubana de Ciencia Agricola 4, 183-186.

Mathison, G. W. \& Milligan, L. P. (1971). British Journal of Nutrition 25, 351-366.

Meggison, P. A., McMenniman, N. P. \& Armstrong, D. G. (1979). Proceedings of the Nutrition Society 38, 147A.

Nolan, J. V. \& MacRae, J. C. (1976). Proceedings of the Nutrition Society 35, 110A.

Ørskov, E. R. \& Macleod, N. A. (1982). Proceedings of the Nutrition Society 41, 76A.

Salter, D. N., Daneshvar, K. \& Smith, R. H. (1979). British Journal of Nutrition 41, 197-209.

Salter, D. N. \& Smith, R. H. (1977a). Proceedings of the Nutrition Society 36, 54A.

Salter, D. N. \& Smith, R. H. (1977b). British Journal of Nutrition 38, 207-216.

Salter, D. N. \& Smith, R. H. (1979). Proceedings of the Japanese Saciety of Animal Nutrition and Metabolism 23, 143-161.

Smith, R. H. (1975). In Digestion and Metabolism in the Ruminant, pp. 399-415 [I. W. McDonald and A. C. I. Warner, editors]. Armidale: University of New England Publishing Unit.

Streeter, C. L., Little, C. O., Mitchell, G. E. \& Scott, R. A. (1973). Journal of Animal Science 37, 796-799. 